\title{
Strength and Density Characteristics of M-30 Concrete Using Coloured Polythene Sheets Curing
}

\author{
Jaison Joy Memadam, T.V.S Vara Lakshmi
}

\begin{abstract}
The process of maintaining the temperature and moisture conditions of concrete is termed as Curing. It is a must for the hydration reaction of concrete to occur which leads to its strength generation. Moisture, heat and time are the different components that constitute curing. Curing directly affects strength, re- sistance to freezing, abrasion and scaling resistance, chemical attack resistance etc. Different methods like shading, covering with gunny or hessian bags, mem- brane curing, and ponding method can be used for curing. In this paper we are using different colored polythene sheets (black, white, blue and pink) for curing. Compressive strengths and density are also compared with normal curing method. A total of 9 cubes are prepared for each type of colored paper curing. Three cubes are then tested at 7, 14 and 28 of curing for compressive strength. This study also identifies the best colored polythene sheet that can be used for curing.
\end{abstract}

Keywords: Polythene sheets curing, Colored paper curing, Hydration, com- pressive strength

\section{INTRODUCTION}

Construction without concrete is unimaginable in this world. It is a combination mixture of cement, aggregates, water and some admixtures in the desired proportions. The ordinary Portland cement (OPC) is the major binder in its constituents. Hydration reaction takes place when the cement is mixed with water. Hydration reaction is the major process that gives strength to the concrete. Water is essential for the hydration reaction to take place. Sometimes water will be lost from concrete by evaporation due to sun. The loss of water may lead to inadequate strength in concrete.

Curing is the process of maintaining the moisture inside the concrete. It can also be achieved by preventing the water to get evaporated. Proper curing helps in reduction of porosity and increasing the density in microstructure in the concrete thus helping the concrete to attain its desired strength and properties. Improper curing leads to pores, shrinkage, chemical attacks and strength defects. So, curing is an important criteria that is required for quality concrete.

\subsection{Types of curing}

There are different categories in the curing process. In the first category, concrete sur- face will be kept wet continuously for a required period (Conventional Curing). In

Revised Version Manuscript Received on 16 September, 2019.

Jaison Joy Memadam, Research Scholar, Department of Civil Engineering, Acharya Nagarjuna University, Guntur, Andhrapradesh, India (Email: jaisonjoy88@gmail.com)

Dr. T.V.S Vara Lakshmi, Assistant professor, Head of Department of Civil Engineering, Acharya Nagarjuna University, Guntur, Andhrapradesh, India the second category, the loss of moisture is minimized by covering the surface with imper- meable membrane (membrane curing). In the third category, concrete surface is kept moist and temperature of the concrete is raised by increasing strength gain rate (Accel- erated curing).

\subsection{Membranes}

Concrete surface can be covered by plastic sheets or polyethylene films. It prevents the water to get evaporated from the concrete. Polyethylene has desirable properties like light weight, moisture barrier and can be easily molded to any shapes. Some patchy discoloration may also be caused by using the polyethylene membrane curing. If cal- cium chloride is present in the concrete, patchy discoloration may be predominant. The polyethylene films should be categorized under ASTM C 171 standard, which specifies $0.10 \mathrm{~mm}$ thickness.

\section{MATERIALS AND METHODS}

\subsection{Cement}

Experiment was carried out by using Ordinary Portland. The physical properties of the cement after the tests are given below.

Table 1. Physical properties of Cement

\begin{tabular}{|l|l|l|}
\hline S.No & Property & Value \\
\hline 1 & Grade & 53 \\
\hline 2 & Specific Gravity & 3.12 \\
\hline 3 & Fineness(cm2/gms) & 2100 \\
\hline 4 & Standard Consistency (\%) & 27 \\
\hline 5 & Initial Setting Time (min.) & 35 \\
\hline 6 & Final Setting Time (min.) & 420 \\
\hline
\end{tabular}

\subsection{Coarse and Fine aggregate}

River sand is used as fine aggregate with a specific gravity of 2.68. The sample is confirming to zone II and fineness modulus is 3.18. Coarse Aggregate used is $10 \mathrm{~mm}$ and $20 \mathrm{~mm}$ crushed gravel of 2.71 specific gravity. Both coarse and fine aggregate was air-dried in the laboratory and sieve analysis was carried out. The fineness modulus was found out to be 7.13 for the coarse aggregate.

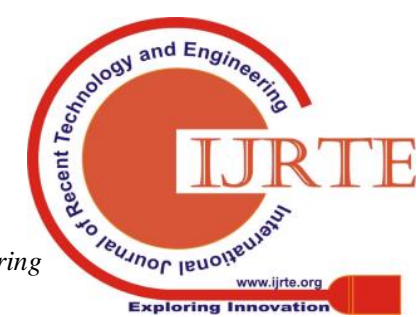




\subsection{Mix Proportions}

The investigation was aimed at studying the compressive strength of M30 grade Con- crete for different type of colored polythene paper curing. The mix proportions are cal- culated based on the IS 10262 and SP 23. The proportions of Cement: Sand: Coarse Aggregate: w/c $=(1: 1.88: 3.38: 0.45)$ was used for mixing.

\subsection{Curing}

The curing were carried out on $150 \mathrm{~mm}$ cube specimens for the ages of 7, 14 and 28 days. The specimens are weighed before curing. The specimens were kept at room temperature for 24 hours and then covered with different types of colored polythene sheets in a closed room with room temperature (Avg. 220 C). Polythene sheets used for the curing are of color black, blue, white and pink. The thickness of polythene sheets used are less than $0.1 \mathrm{~mm}$ as per the standards

\subsection{Compressive strength and Density}

The compressive strength of the concrete cube was determined by using a Compressive strength testing machine. Three cube specimens were tested at 7,14 and 28 days of curing. Density of the concrete is determined for cubes by weighing it and then dividing it by its volume for each type of colored paper curing.

\section{RESULTS AND DISCUSSION}

Compression testing machine of $2000 \mathrm{kN}$ was used for finding the compressive strength at 7,14 and 28 days of curing.

Table 2. Compressive strength after 7 days of curing

\begin{tabular}{|l|l|l|l|l|l|}
\hline S.No & $\begin{array}{l}\text { Type } \\
\text { curing }\end{array}$ & $\begin{array}{l}\text { of } \\
\text { Sample 1 } \\
(\mathbf{M P a})\end{array}$ & $\begin{array}{l}\text { Sample 2 } \\
(\mathbf{M P a})\end{array}$ & $\begin{array}{l}\text { Sample 3 } \\
(\mathbf{M P a})\end{array}$ & $\begin{array}{l}\text { Average } \\
\text { (MPa) }\end{array}$ \\
\hline 1 & $\begin{array}{l}\text { Normal } \\
\text { Curing }\end{array}$ & 24.63 & 24.74 & 24.82 & 24.73 \\
\hline 2 & $\begin{array}{l}\text { Black } \\
\text { Polythene }\end{array}$ & 21.13 & 20.97 & 21.30 & 21.13 \\
\hline 3 & $\begin{array}{l}\text { Blue } \\
\text { Polythene }\end{array}$ & 21.6 & 21.45 & 21.96 & 21.67 \\
\hline 4 & $\begin{array}{l}\text { White } \\
\text { Polythene }\end{array}$ & 23.4 & 23.19 & 23.71 & 23.25 \\
\hline 5 & $\begin{array}{l}\text { Pink } \\
\text { Polythene }\end{array}$ & 22.35 & 22.48 & 22.34 & 22.39 \\
\hline
\end{tabular}

Table 3. Compressive strength after 14 days of curing

\begin{tabular}{|l|l|l|l|l|l|}
\hline $\begin{array}{l}\text { S.N } \\
\text { o }\end{array}$ & $\begin{array}{l}\text { Type } \\
\text { curing }\end{array}$ & $\begin{array}{l}\text { Sample 1 } \\
\text { (MPa) }\end{array}$ & $\begin{array}{l}\text { Sample 2 2 } \\
\text { (MPa) }\end{array}$ & $\begin{array}{l}\text { Sample 3 3 } \\
\text { (MPa) }\end{array}$ & $\begin{array}{l}\text { Average } \\
\text { (MPa) }\end{array}$ \\
\hline 1 & $\begin{array}{l}\text { Normal } \\
\text { Curing }\end{array}$ & 34.64 & 35.24 & 34.84 & 34.91 \\
\hline 2 & $\begin{array}{l}\text { Black } \\
\text { Polythene }\end{array}$ & 29.54 & 29.48 & 30.15 & 29.72 \\
\hline 3 & $\begin{array}{l}\text { Blue } \\
\text { Polythene }\end{array}$ & 30.42 & 30.12 & 30.94 & 30.49 \\
\hline 4 & $\begin{array}{l}\text { White } \\
\text { Polythene }\end{array}$ & 32.58 & 32.14 & 32.86 & 32.53 \\
\hline 5 & $\begin{array}{l}\text { Pink } \\
\text { Polythene }\end{array}$ & 31.25 & 31.47 & 30.92 & 31.21 \\
\hline
\end{tabular}

Table 4. Compressive strength after 28 days of curing

\begin{tabular}{|l|l|l|l|l|l|}
\hline $\begin{array}{l}\text { S.N } \\
\mathbf{0}\end{array}$ & $\begin{array}{l}\text { Type } \\
\text { curing }\end{array}$ & $\begin{array}{l}\text { of Sample } \\
\mathbf{1} \\
(\mathbf{M P a})\end{array}$ & $\begin{array}{l}\text { Sample } \\
\mathbf{( M P a}\end{array}$ & $\begin{array}{l}\text { Sample } \\
\mathbf{3} \\
(\mathbf{M P a})\end{array}$ & $\begin{array}{l}\text { Average } \\
(\mathbf{M P a})\end{array}$ \\
\hline 1 & $\begin{array}{l}\text { Normal } \\
\text { Curing }\end{array}$ & 38.68 & 39.54 & 38.12 & 38.78 \\
\hline 2 & $\begin{array}{l}\text { Black } \\
\text { Polythene }\end{array}$ & 32.57 & 32.93 & 32.78 & 32.76 \\
\hline 3 & $\begin{array}{l}\text { Blue } \\
\text { Polythene }\end{array}$ & 33.47 & 33.53 & 33.87 & 33.62 \\
\hline 4 & $\begin{array}{l}\text { White } \\
\text { Polythene }\end{array}$ & 35.54 & 34.85 & 35.21 & 34.87 \\
\hline 5 & $\begin{array}{l}\text { Pink } \\
\text { Polythene }\end{array}$ & 34.24 & 34.81 & 34.04 & 34.36 \\
\hline
\end{tabular}

Table 5. Density of concrete before curing

\begin{tabular}{|l|l|l|l|l|l|}
\hline $\begin{array}{l}\text { S.N } \\
\mathbf{0}\end{array}$ & $\begin{array}{l}\text { Type } \\
\text { curing }\end{array}$ & $\begin{array}{l}\text { of Sample } \\
\mathbf{1} \\
(\mathbf{k g} / \mathbf{m 3})\end{array}$ & $\begin{array}{l}\text { Sample } \\
\mathbf{2} \\
(\mathbf{k g} / \mathbf{m 3})\end{array}$ & $\begin{array}{l}\text { Sample } \\
\mathbf{3} \\
(\mathbf{k g} / \mathbf{m 3})\end{array}$ & $\begin{array}{l}\text { Average } \\
(\mathbf{k g} / \mathbf{m 3})\end{array}$ \\
\hline 1 & $\begin{array}{l}\text { Normal } \\
\text { Curing }\end{array}$ & 2658 & 2748 & 2878 & 2761 \\
\hline 2 & $\begin{array}{l}\text { Black } \\
\text { Polythene }\end{array}$ & 2578 & 2688 & 2582 & 2616 \\
\hline 3 & $\begin{array}{l}\text { Blue } \\
\text { Polythene }\end{array}$ & 2687 & 2576 & 2579 & 2614 \\
\hline 4 & $\begin{array}{l}\text { White } \\
\text { Polythene }\end{array}$ & 2884 & 2775 & 2686 & 2781 \\
\hline 5 & $\begin{array}{l}\text { Pink } \\
\text { Polythene }\end{array}$ & 2589 & 2604 & 2598 & 2597 \\
\hline
\end{tabular}

Table 5. Density of concrete After 28 days of curing

\begin{tabular}{|l|l|l|l|l|l|}
\hline $\begin{array}{l}\text { S.N } \\
\mathbf{0}\end{array}$ & $\begin{array}{l}\text { Type of } \\
\text { curing }\end{array}$ & $\begin{array}{l}\text { Sample } \\
\mathbf{1} \\
(\mathbf{k g} / \mathbf{m 3})\end{array}$ & $\begin{array}{l}\text { Sample } \\
\mathbf{2} \\
(\mathbf{k g} / \mathbf{m 3})\end{array}$ & $\begin{array}{l}\text { Sample } \\
\mathbf{3} \\
(\mathbf{k g} / \mathbf{m 3})\end{array}$ & $\begin{array}{l}\text { Average } \\
\mathbf{k g} / \mathbf{m 3})\end{array}$ \\
\hline 1 & $\begin{array}{l}\text { Normal } \\
\text { Curing }\end{array}$ & 2714 & 2847 & 2956 & 2839 \\
\hline 2 & $\begin{array}{l}\text { Black } \\
\text { Polythene }\end{array}$ & 2415 & 2578 & 2497 & 2497 \\
\hline 3 & $\begin{array}{l}\text { Blue } \\
\text { Polythene }\end{array}$ & 2662 & 2545 & 2548 & 2585 \\
\hline 4 & $\begin{array}{l}\text { White } \\
\text { Polythene }\end{array}$ & 2845 & 2752 & 2648 & 2756 \\
\hline 5 & $\begin{array}{l}\text { Pink } \\
\text { Polythene }\end{array}$ & 2541 & 2579 & 2567 & 2562 \\
\hline
\end{tabular}




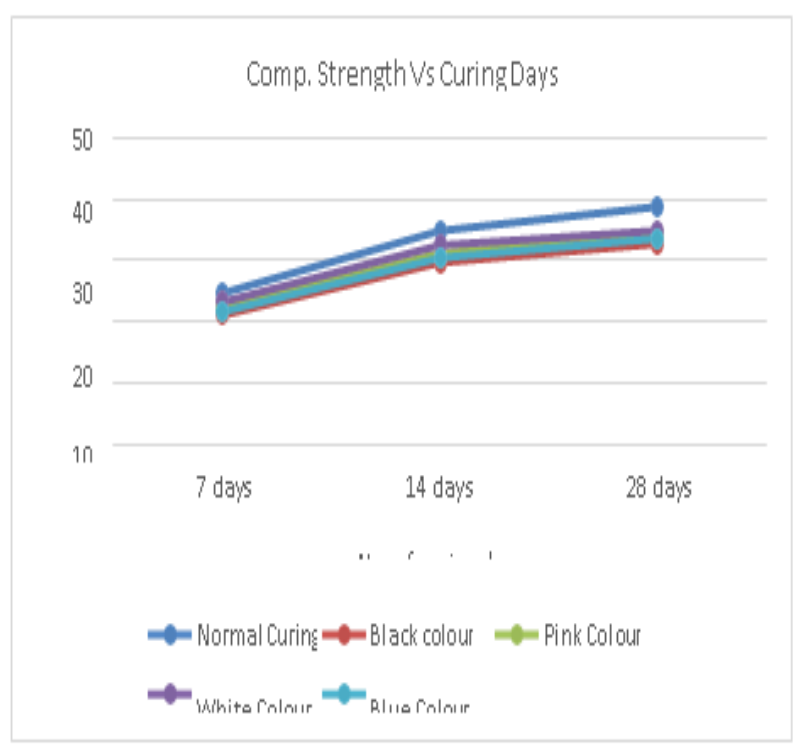

Fig. 1. Compressive strength of cubes

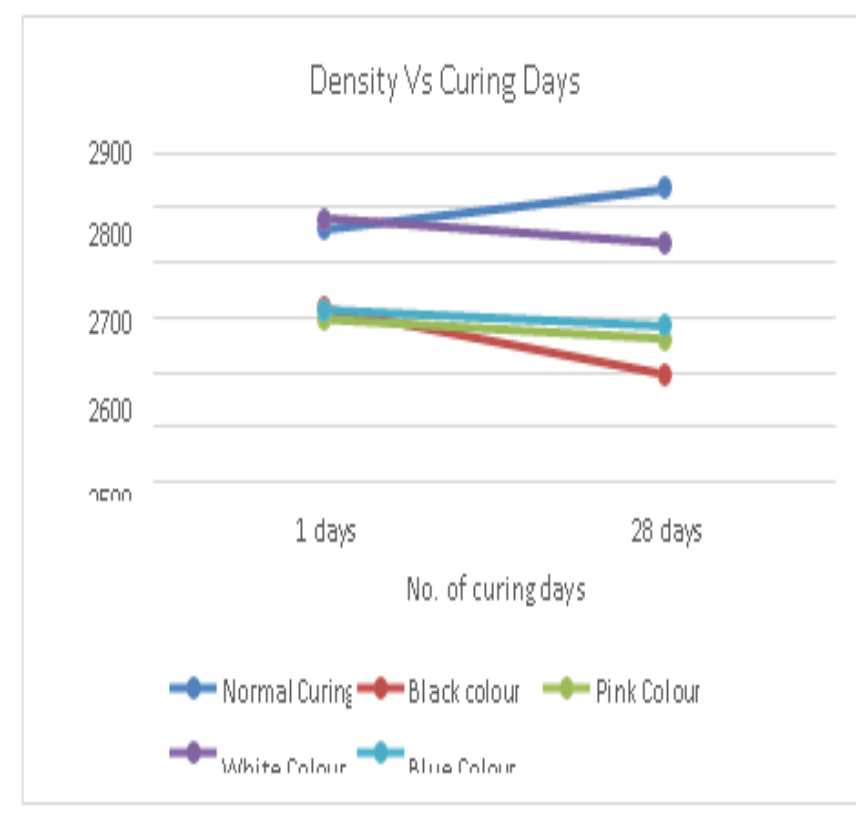

Fig. 2. Density of cubes

\section{CONCLUSIONS}

The following conclusions were made from the results.

1. Colored Polythene sheets can be used as membrane curing for concrete wherever there is water scarcity.

2. White color polythene sheet gave the maximum strength when compared to other colored polythene sheets, when used for curing.

3. Blue, Pink and Black polythene sheets curing also resulted in substantial gain in compressive strength.

4. There is a slight decrease in density after curing of the concrete using polythene sheet.

5. Loss of density is minimum for White polythene sheet and maximum for Black color polythene sheet.

\section{REFERENCES}

1. Al-Gahtani AS. Effect of curing methods on the properties of plain and blended cement concretes. Construction and Building Materials 2010; 24: 308-314.

2. ASTM standards

3. El- Reedy, "The concrete Industry", Advanced materials and techniques for reinforced Con- crete Structures, 2009
4. IS 10262-2009: Recommended Guidelines for Concrete Mix design

5. IS 2386 - 1963: Methods of Test for Aggregates for Concrete.

6. IS 383 - 1970: Specification for Coarse and fine Aggregates from Natural Sources for Con- crete.

7. Klieger, P.H. (1958); Effect of Mixing and Curing on Concrete Strength. ACI Journal, Pro- ceeding, 4(12); 1063-1081.

8. M.A. El-Reedy, Advance materials and techniques for reinforced concrete structure (New York, NY: Taylor \& Francis, 2009)

9. Mamlouk MS, Zaniewski JP. Materials for civil and construction engineers, second edition. Pearson Education, Inc., New Jersey, 2006.

10. Mehta and Monteiro (1993); Concrete Structure, Properties and Materials; Prentice-Hall, Englewood Cliffs

11. Neville A.M. (1996); Properties of concrete, Fifth Edition, Wesley Longman Ltd, London

12. Siddiqui MS, Nyberg W, Smith W, Blackwell B, Riding KA. Effect of curing water availa- bility and composition on cement hydration. ACI Materials Journal 2013; 110(3): 315-322.

13. SP - 23: Hand Book on Concrete Mixes

14. Yazicioglu S, Caliskan S, Turk K. Effect of curing conditions on the engineering properties of self-compacting concrete. Indian Journal of Engineering \& Materials Sciences 2006; 13(1): 25-29. 